\title{
Suriye İç Savaşında Göç ve Kadın
}

\author{
Asiye Bekarca Şen ${ }^{1}$ \\ Cem Vural ${ }^{2}$
}

\begin{abstract}
$\ddot{O} z$
15 Mart 2011 tarihinde, Suriye muhalefetinin, Baas iktidarına karşı gösterileriyle Suriye'deki olaylar başlamış ve bugün karşılıklı olarak silahlı çatışma halinde devam etmektedir. $\dot{I}_{C}$ karış̧ılı̆̆ın üçüncü yılında yaklaşı 100.000 kişi hayatını kaybetmiş ve 1.948.746 Suriyeli vatandaş kendi ülkesini terk ederek Türkiye, Irak, Lübnan, Ürdün ve Mısır'a slğınmacı olarak yerleşmiştir. Ülkelerini terk eden nüfusun \% 75 'ini kadınlar ve çocuklar oluşturmaktadır. Suriyeli sığınmacılar ilk olarak Türkiye'ye Nisan 2011 yılında gelmeye başladılar. Türkiye Başbakanlık Afet ve Acil Durum Yönetimi Başkanlı̆̆ı'nın (AFAD) yeterli ve gerekli alt yapıyı çok kısa sürede oluşturması ve açık kapı politikası izlemesi sonucu Suriyeliler tarafindan öncelikli tercih edilen ülke olmuştur. Ağustos 2013 tarihi itibariyle Türkiye'de 14 çadır kent ve 6 konteyner kent kurulmuştur, kamp içinde 200.150 ve kamp dışında yaklaşı 300.000 olmak üzere toplam 500.150 Suriyeli siğınmacı barınmaktadır. AFAD tarafindan gerçekleştirilen Suriyelilerin memnuniyetini ölçmeye yönelik olarak yapılan araştırmaya göre kamp içi ve kamp dışındaki Suriyelilerin \%50'si kadın \%50'si ise erkeklerden oluşmaktadır. Yaş gruplarına baktığımız zaman ise \%33'ünü 0-11 yaş, \%40'nı 12-30 yaş aralığındadır. Genel olarak nüfusun \%70'ni 30 yaş altı oluştururken nüfusun genç ve bağımlı bir yapıya sahip olduğu görülmektedir. Anket sonuçları göstermektedir ki Suriyelilerin \%60'nı bekârlar, bekârların da \%46’sını kadınlar oluşturmaktadır. Kadınların çoğu ilkokul mezunu ve ev kadınıdır. Üniversite mezunları ise genellikle öğretmenlik yaparken ikinci sırayı yine ev kadınlığ almaktadır. Kadınlar, imkân tanınırsa genellikle toplumda kadına biçilen roller çerçevesinde terzilik, temizlik, tarım vb. işler yapmak istiyorlar. Türkiye'de Suriyeli kadınların sadece \%2'si aktif olarak çalışmaktadır. İhtiyaçlar açısından araştırma bulgularına bakıldiğında, çocuk bezi ve kadınlara yönelik özel ihtiyaçlara ulaşmakta kamp içi ve kamp dışında önemli farklıllklara rastlanmaktadır. Bu makalede AFAD tarafindan gerçekleştirilen anket verilerinin yanı sıra Türkiye'de bulunan Suriyeli kadınlara dair gerçek hikâyeler anlatılmaktadır.
\end{abstract}

Anahtar Sözcükler: AFAD, İ̧ savaş, Kamp dışı, Kamp içi, Suriyeli kadın

\section{Migration and Women in Syrian Civil War}

\begin{abstract}
On 15 March 2011, the conflict in Syria began with the demonstrations of Syrian opposition against the Baath party and today it continues mutually in armed conflicts. In the third year of the internal conflict, approximately 100.000 people have lost their lives and 1.948.746 Syrian citizens by leaving their own countries have settled in Turkey, Iraq, Lebanon, Jordan and Egypt as refugees. Women and children comprise $75 \%$ of the population who have left their own countries. Syrian refugees have firstly started to come to Turkey in April of 2011. Turkey has become the country which is primarily preferred as a result of AFAD's building of sufficient and necessary infrastructure in a very short time and its open-door policy. As the date of August 2013, 14 tent cities and 6 container cities have been built; 500.150 Syrian citizens, 200.150 of which inside the camps and approximately 300.000 of which outside the camps inhabit in Turkey. According to a research conducted by AFAD with the aim of measuring the satisfaction of Syrians, $50 \%$ of Syrians living inside and outside the camps are men and $50 \%$ of them are women. When we look at the age groups, ages 0 to 11 constitute $33 \%$ of the population while ages 12 to 30 constitute $40 \%$ of the population. In general, it is observed that $70 \%$ of the population consists of people under the age of 30 and that population is young and dependent. The survey results show that $60 \%$ of Syrians are single and $46 \%$ of single people
\end{abstract}

1 Sosyal Çalışmacı, Başbakanlık Afet ve Acil Durum Yönetimi Başkanlığı, 0312 2582323, asiye.sen@afad.gov.tr 2 AFAD Uzm.Yrd .Başbakanlık Afet ve Acil Durum Yönetimi Başkanlığı, 0312 2582323, cem.vural@afad.gov.tr 
are women. Most of women are primary school graduates or housewives. While university graduates are working as teachers in general, being a housewife comes secondly. In case of providing, women are willing to do jobs in accordance with gender roles like tailoring, cleaning, agriculture etc. Only $2 \%$ of Syrian women are included in active workforce in Turkey. When research findings are evaluated regarding the needs, it is encountered that there is a significant difference in accessing the diapers and the requirements special to women between inside and outside the camps. In this article, in addition to the results of the survey conducted by AFAD, the real stories of Syrian women in Turkey are explained as well.

Keywords: AFAD, Civil War, Outside the Camp, Inside the Camp, Syrian women

\section{Giriş}

$\mathrm{Bu}$ çalışmada hiçbir siyasi amaç güdülmeden ve taraf tutulmadan Suriye iç savaşında göç olgusu ile Türkiye'deki Suriyeli kadın profilini ortaya koymak ve saha çalışmalarından elde edilen bilgilerin bir kısmını paylaşmak amaçlanmıştır. Bu çalışmada sunulan veriler 26 Eylül 2013 tarihine aittir ve Suriye iç savaşı devam ettiği için sayılar değişkenlik göstermektedir.

Savaş bir yıkım ve yok oluş sürecidir. Bu süreç çoğu zaman beraberinde zorunlu göçü getirmektedir. Zorunlu göç ile insanlar genellikle devletlerin siyasi, ekonomik ve sosyal bazı yaptırımları nedeniyle çevrelerini terk etmek zorunda kalırlar (Aker ve diğer, 2002; Buz, 2008). Yakın tarihimize baktığımız zaman zorunlu göç olgusunun yaşandığı birçok örnek görmek mümkün:

- 1979 yılında İran'da Şah rejiminin yıkılarak Humeyni rejiminin kurulması ve İran-Irak savaşının ardından 1.000 İran vatandaşının Türkiye’ye sığınması,

- 1989 yılında Bulgaristan'da artan insan ihlalleri sonucu 300.000'i aşkın Türk kökenli Bulgar vatandaşının Türkiye'ye sığınması,

- 1991 Körfez Savaşı’nda 500.000 Iraklı Türk’ün Türkiye’ye sığınması,

- 1992 Yugoslavya iç savaşı sonucu 25.000 Bosnalının Türkiye’ye sığınması,

- 1999 yılında Sırpların Kosovalı Arnavutlara saldırması sonucu 20.000'i aşkın mültecinin Türkiye'ye sığınması bu örneklerden bazılarıdır (Buz, 2008; Çolak, 2013; Çetin, 2008).

$\mathrm{Bu}$ süreçte en çok siviller zarar görmektedir ve bunların \% 70'ini kadınlar ve çocuklar oluşturmaktadır. Toplumsal cinsiyet farklılıkları savaş sürecinde de kendini göstermektedir. Kadınlar; toplumsal cinsiyet temelli ayrımcilık, sosyal ve kültürel önyargılardan kaynaklanan baskı ve zulüm, geleneklerle ilişkili bedensel ve ruhsal sağlıklarını bozan zarar verici uygulamalar, cinsel istismar, cinsel şiddet, aile içi şiddet gibi esas olarak kadın olmalarından kaynaklanan zulüm ve baskılardan kaçmak için de ülkelerini terk etmek ve başka bir ülkeye göç etmek zorunda kalırlar (Akkaya, 2002; Moghadam, 2005; International Federation For Human Rigts, 2012). Bu göçün sığınmacı kadınlar üzerindeki etkileri; kadınların istismar, sömürü ve şiddete daha açık olması, verilen hizmetlere sınırlı ulaşmaları, göçle birlikte toplumsal cinsiyet rollerindeki değişimler, kadınların hareketlilik olanaklarının sınırlılığı, psikolojik olarak etkilenmeleri, ekonomik durumun değişimi ile bağlantılı sorunlar, kimliğin yeniden inşası ve sığınmacı olarak tanımlanmayla ilgili farklılıklardır (Buz, 2006).

Suriye'de 2011 y1lından bu yana devam eden savaş ve çatışma ortamında 100.000 kişi hayatını kaybetmiş ve 1.911.282 Suriye vatandaşı ülkesini terk ederek Lübnan, Ürdün, Türkiye ve Irak'a sığınmıştır. Ülkelerini terk eden nüfusun \% 75'ini kadınlar ve çocuklar oluşturmaktadır (The UN Refugee Agency[UNHCR], 2013). Türkiye'ye Nisan 2011 y1lından itibaren gelmeye başlayan Suriye vatandaşlarına Başbakanlık Afet ve Acil Durum Yönetimi Başkanlığı (AFAD) tarafindan geçici koruma sağlanmıştır. Türkiye Cumhuriyeti, sınırları içinde bulunan Suriye vatandaşlarını "geçici 
koruma altına alınan Suriye vatandaşları” olarak tanımlamıştır. AFAD’ın yeterli ve gerekli alt yapıyı çok kısa sürede oluşturması, açık kapı politikası izlemesi ve yardımların devlet eli ile yapılıyor olması sonucu Suriyeliler tarafından tercih edilen öncelikli ülke haline gelmiştir. Ağustos 2013 tarihi itibariyle 10 ilde 14 çadır kent ve 6 konteyner kent kurulmuştur (Afet ve Acil Durum Yönetimi Başkanlığ 1 [AFAD], 2013). Kamp içinde 200.150 ve kamp dışında yaklaşık 300.000 olmak üzere toplam 500.150 Suriye vatandaşı barınmaktadır. Oluşturulan barınma merkezlerinde ilgili bakanlık, kamu kurum ve kuruluşları ve Türk Kızılay’ı ile birlikte barınma, yiyecek, sağlık, güvenlik, sosyal aktivite, eğitim, ibadet, tercümanlık, haberleşme, bankacılık ve diğer birçok hizmet verilmektedir. Ayrıca okul, cami, çocuk oyun alanları, sağlık merkezleri gibi sosyal donatılarda bulunmaktadır. Barınma merkezlerinin dışında bulunan yaklaşı 300.000 Suriye vatandaşının günlük insani ihtiyaçları ve sağlık hizmetleri Başbakanlık AFAD koordinasyonunda sağlanmaya çalışılmaktadır(AFAD, 2013).

\section{Yöntem}

$\mathrm{Bu}$ araştırma nitel (kalitatif) ve nicel (kantitatif) araştırma yöntemleri kullanılarak hazırlanmıştır. Tarama modelinde betimsel bir çalışmadır. Suriye vatandaşları ile dil problemi yaşandığı için her iki veri toplama yönteminde tercüman kullanılmıştır.

Nicel araştırma, Suriye'deki iç karışıklıklar nedeniyle ülkemize gelerek geçici barınma merkezlerinde veya kendi imkânları ile barınma merkezlerinin dışında ikamet eden Suriye vatandaşlarının ihtiyaçlarının, sorunlarının, memnuniyet düzeylerinin ve gelecek beklentilerinin belirlenmesi amacıyla Başbakanlık AFAD tarafından 23 Haziran - 6 Temmuz 2013 tarihleri arasında gerçekleştirilmiştir. Bu araştırma kapsamında nicel araştırma verilerinin tamamına değil kadın ile ilgili olan kısımlarına yer verilmiştir.

Geçici barınma merkezlerinin bulunduğu 10 ilde, 20 barınma merkezi ve bu 10 ilde barınma merkezi dışında yaşayan Suriye vatandaşlarından rastgele örnekleme yöntemiyle seçilen; barınma merkezlerinde yaşayan 1.420 hane (hane reisi), barınma merkezlerinin dışında yaşayan 1.159 hane (hane reisi), toplamda 2579 hane (hane reisi) ile yüz yüze görüşme yöntemi ile barınma merkezlerinden 7.859, barınma merkezlerinin dışından 7.326, toplamda 15.185 kişiye ait (hanede yaşayan bireylere ait) veri elde edilmiştir.

Nitel araştırma, geçici barınma merkezlerinin bulunduğu Kilis ilinde barınma merkezinde yaşayan ve birebir görüşme talep eden kişiler ile yapılan psikososyal destek görüşmeleri çerçevesinde kadınların Suriye'de iken neler yaşadıklarını, göçleri sırasında nelere tanık oldukları ve şu anki durumları araştırılmıştır. Her kadın ile en az 3 görüşme gerçekleştirilmiştir.

\section{Bulgular ve Yorum}

\section{İstatistiki Veri}

Türkiye'ye sı̆̆ınan Suriye vatandaşları Adana, Adıyaman, Gaziantep, Hatay, Kahramanmaraş, Kilis, Malatya, Mardin, Osmaniye ve Şanlıurfa' da kurulan barınma merkezlerine yerleştirilmişlerdir.

Barınma merkezleri dışına yerleşen Suriye vatandaşları barınma merkezlerinin bulunduğu illerin şehir merkezlerinin yanı sıra Mersin, İstanbul, Ankara, Konya gibi illere yerleşmişlerdir. Türkiye’ye sığınan Suriye vatandaşlarının \%67'si güvenlik nedeniyle göç etmiştir. 
Tablo1. Görüşülen Suriye vatandaşlarının cinsiyet dağılımı.

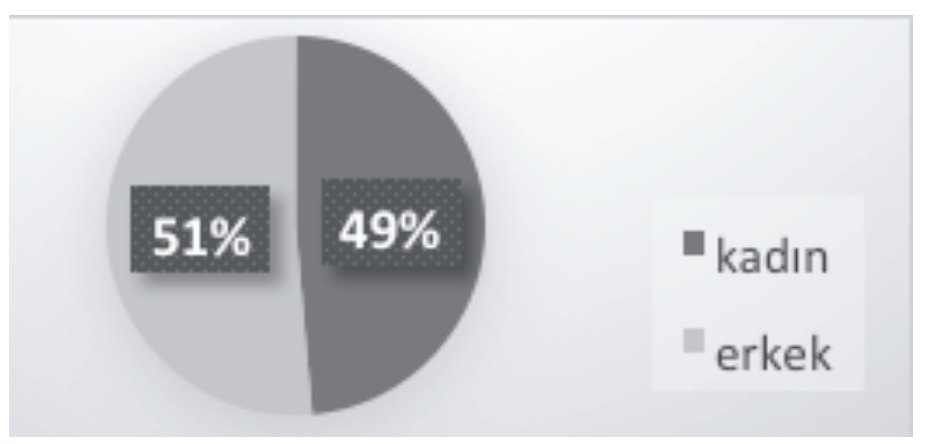

Tablo 1'de Suriye vatandaşlarının cinsiyet dağılımı kamp içinde ve dışında paralellik göstermektedir. Suriye vatandaşlarının \% 49'unu kadınlar, \%51'ini erkekler oluşturmaktadır.

Tablo 2. Görüşülen Suriye vatandaşlarının yaş dağılımı

\begin{tabular}{ccc} 
Yaş Grubu & Erkek & Kadın \\
\hline 0-12 Yaş & $35,0 \%$ & $35,8 \%$ \\
\hline 13-18 Yaş & $15,6 \%$ & $15,7 \%$ \\
\hline 19-54 Yaş & $44,1 \%$ & $43,3 \%$ \\
\hline 55-64 Yaş & $3,4 \%$ & $3,1 \%$ \\
\hline 65 + Yaş & $1,9 \%$ & $2,1 \%$ \\
\hline Toplam & $\mathbf{1 0 0 , 0 \%}$ & $\mathbf{1 0 0 , 0 \%}$
\end{tabular}

Tablo 2'de kadınların yaş aralıklarının dağılımlarına baktığımız zaman erkekler ile paralellik gösterdiğini söyleyebiliriz. Suriye vatandaşlarının nüfusunun genel olarak genç bir nüfus yapısına sahip olduğunu görüyoruz. 0-18 yaş aralığ yaklaşık \%50'lik bir paya sahipken, nüfusun yaklaşık $\% 5$ 'ini 55 ve üstündekiler oluşturmaktadır.

Tablo 3. Görüşülen Suriyeli vatandaşların medeni durumu

\begin{tabular}{ccc} 
Medeni Durum & Erkek & Kadın \\
\hline Bekâr & $63,5 \%$ & $56,9 \%$ \\
\hline Evli & $36,1 \%$ & $39,8 \%$ \\
\hline Eşi Ölmüş & $0,4 \%$ & $2,7 \%$ \\
\hline Boşanmış & $0,1 \%$ & $0,6 \%$ \\
\hline Toplam & $\mathbf{1 0 0 , 0 \%}$ & $\mathbf{1 0 0 , 0 \%}$ \\
\hline
\end{tabular}

Tablo 3'te kadınların \% 56,9'unu, erkeklerin \% 63,5'ini bekârlar oluşturmaktadır. Ülkenin genç bir nüfusa sahip olmasından dolayı bekâr oranının yüksekliği göze çarpmaktadır. Buna bağlı olarak nüfusun genç ve bağımlı bir yapıya sahip olduğu söylenebilir. 
Tablo 4. Görüşülen Suriye vatandaşlarının eğitim düzeyi

\begin{tabular}{ccc} 
Eğitim Durumu & Erkek & Kadın \\
\hline Okur-yazar değil & $12,1 \%$ & $19,0 \%$ \\
\hline Okur-yazar & $6,8 \%$ & $8,1 \%$ \\
\hline İlkokul & $34,2 \%$ & $35,4 \%$ \\
\hline Ortaokul & $23,6 \%$ & $20,6 \%$ \\
\hline Lise & $12,5 \%$ & $10,4 \%$ \\
\hline Üniversite & $10,9 \%$ & $6,5 \%$ \\
\hline Toplam & $\mathbf{1 0 0 , 0 \%}$ & $\mathbf{1 0 0 , 0 \%}$
\end{tabular}

Tablo 4'te eğitim düzeyi yakından incelendiğinde; ilkokul mezunu ve daha alt düzey eğitim seviyelerinde kadın oranı yüksekken, ilkokul mezunu ve daha üst düzey eğitim seviyelerinde erkek oranının yüksek olduğunu görüyoruz. Genel olarak Suriye toplumunda kadınların erkeklere göre daha düşük okullaşma oranına sahip olduğu söylenebilir.

Tablo 5. Görüşülen Suriye vatandaşlarının mesleki dă̆ılımı

\begin{tabular}{|c|c|c|c|c|}
\hline \multicolumn{2}{|r|}{$\begin{array}{c}\text { Kamp Dışında Yaşayan } \\
\text { Suriyelilerin Mesleği }\end{array}$} & \multirow{2}{*}{$\begin{array}{l}\text { Erkek } \\
13,0 \%\end{array}$} & \multirow{2}{*}{$\begin{array}{l}\text { Kadın } \\
0,5 \%\end{array}$} & \multirow{2}{*}{$\begin{array}{l}\text { Toplam } \\
7,2 \% \\
\end{array}$} \\
\hline 1. & El İşçiliği & & & \\
\hline 2. & Ofis Çalışanı & $3,6 \%$ & $0,5 \%$ & $2,2 \%$ \\
\hline 3. & Ordu Çalışanı & $0,9 \%$ & $0,0 \%$ & $0,5 \%$ \\
\hline 4. & Sağlık Çalışanı & $1,2 \%$ & $0,6 \%$ & $0,9 \%$ \\
\hline 5. & Zanaatkâr & $16,8 \%$ & $1,6 \%$ & $9,7 \%$ \\
\hline 6. & Mimar-Mühendis-Müteahhit & $2,6 \%$ & $0,3 \%$ & $1,6 \%$ \\
\hline 7. & Hukukçu & $1,3 \%$ & $0,2 \%$ & $0,8 \%$ \\
\hline 8. & Tarım ve Hayvancılık & $6,1 \%$ & $0,9 \%$ & $3,7 \%$ \\
\hline 9. & Hükümet Çalışanı & $7,9 \%$ & $4,8 \%$ & $6,4 \%$ \\
\hline 10. & Yazar - Sanatçı & $0,9 \%$ & $0,0 \%$ & $0,5 \%$ \\
\hline 11. & Operatör & $5,6 \%$ & $0,1 \%$ & $3,0 \%$ \\
\hline 12. & Mesleği Yok & $17,9 \%$ & $86,5 \%$ & $49,9 \%$ \\
\hline 13. & STK Çalışanı & $0,1 \%$ & $0,0 \%$ & $0,0 \%$ \\
\hline 14. & Siyasi Parti Çalışanı & $0,0 \%$ & $0,0 \%$ & $0,0 \%$ \\
\hline 15. & Diğer & $22,1 \%$ & $4,0 \%$ & $13,6 \%$ \\
\hline & Toplam & $100,0 \%$ & $100,0 \%$ & $100,0 \%$ \\
\hline
\end{tabular}


Tablo 5 'te meslek dağılımında ise çalışma hayatında özelikle yüksek statülü meslek kollarında erkek egemenliği göze çarpmakta olup, mesleği olmayan kadın oranının \%86,5 gibi yüksek bir oran olduğunu görüyoruz. Erkeklerde ise bu oran \%17,9 olarak karşımıza çıkmaktadır.

Tablo 6. Görüşülen Suriye vatandaşlarının aile üyelerinden birinin psikososyal destek ihtiyacı olduğunu düşünen aile dağılımı

\begin{tabular}{lcc} 
Psikolojik Desteğe İhtiyaç Olup Olmadığı & Erkek & Kadın \\
\hline İhtiyaç Olduğunu Düşünüyorum & $48,3 \%$ & $51,9 \%$ \\
\hline İhtiyaç Olduğunu Düşünmüyorum & $51,7 \%$ & $48,1 \%$ \\
\hline Toplam & $100,0 \%$ & $100,0 \%$
\end{tabular}

Tablo 6'da psikososyal desteğe ihtiyaç duyanlarının yaklaşık \%52'sini kadınlar, \%48'ini erkeklerin oluşturduğu görülmektedir. Genel olarak ise nüfusun yaklaşık yarısının psikososyal desteğe ihtiyaç duyduğu görülmektedir.

Tablo 7. Görüşülen Suriye vatandaşlarından hanesinde hamile kadın bulunan aile dă̆ıllımı

\begin{tabular}{lc} 
Hanede Hamile Aile Bireyi Olup Olmadığı & Yüzde \\
\hline Hamile Birey Var & $13,2 \%$ \\
\hline Hamile Birey Yok & $86,8 \%$ \\
\hline Toplam Yüzde & $100,0 \%$
\end{tabular}

Tablo 7'de hanesinde hamile kadın bulunan aile oranı 13,2 olarak karşımıza çıkmaktadır. Hamile kadınlar incinebilir grup kapsamında değerlendirildiği için hamile kadınların özel bakım ve ihtiyaçlarının göz önünde bulundurulması gerekmektedir.

Tablo 8. Görüşülen Suriye vatandaşlarından Türkiye'ye geldikten sonra hanesinde doğum yapan kadın dă̆ılımı

\begin{tabular}{lc} 
Hanede Doğum Yapan Kadın Olup Olmadı̆̆ı & Yüzde \\
\hline Doğum Yapan Kadın Var & $7,6 \%$ \\
\hline Doğum Yapan Kadın Yok & $92,4 \%$ \\
\hline Toplam Yüzde & $100,0 \%$
\end{tabular}

Tablo 8'de Suriye vatandaşlarının Türkiye'ye geldikten sonra hanesinde doğum yapan kadın oranı \% 7,6'dır. Buna bağlı olarak da özel ihtiyaç bakım ve ihtiyaç gereksinimi duyan haneler bulunduğu söylenebilir. 
Tablo 9. Görüşülen Suriye vatandaşlarından Türkiye ye geldikten sonra doğum yapan kadınların nerede doğum yaptıklarının dă̆ılımı

\begin{tabular}{lc} 
Doğumun Nerede Gerçekleştiği & Yüzde \\
\hline Evde & $1,1 \%$ \\
\hline Kampta & $2,1 \%$ \\
\hline Hastane ya da Klinikte & $96,3 \%$ \\
\hline Diğer & $0,5 \%$ \\
\hline Toplam Yüzde & $100,0 \%$ \\
\hline
\end{tabular}

Tablo 9'da sağlık kuruluşunda doğum yapanların oranı 96,3'tür. Türkiye'de kadınların doğum esnasında sağlık hizmetlerine ulaşmakta büyük bir sorun yaşamadığı söylenebilir.

Tablo 10. Görüşülen Suriye vatandaşlarından kötü muamele ile karşılaştıklarında nereye başvurmaları gerektiğini bilip-bilmediğinin dă̆ılımı

\begin{tabular}{llc} 
Kötü Muamele İle Karşılaştıklarında Nereye & \multicolumn{2}{c}{ Cinsiyet } \\
$\begin{array}{l}\text { Başvurmaları Gerektiğini Bilip Bilmeme } \\
\text { Durumu }\end{array}$ & Erkek & \multicolumn{1}{c}{ Kadın } \\
\hline Biliyor & $54,6 \%$ & $48,1 \%$ \\
\hline Bilmiyor & $45,4 \%$ & $51,9 \%$ \\
\hline Toplam Yüzde & $100 \%$ & $100 \%$
\end{tabular}

Tablo 10'da kadınların \% 48,1'i kötü muamele ile karş1laştığında nereye başvurabileceğini bilirken; \% 51,9'u nereye başvurabileceğini bilmemektedir. Oranların birbirine yakın olduğu görülse de erkeklerde bunun tam tersi olduğu görülmektedir.

Tablo 11. Kamp içinde görüşülen Suriyeli kadınlara imkân sağlanırsa üretim yapmak isteyipistemediklerinin dăğlımı

\begin{tabular}{llc}
$\begin{array}{l}\text { Kamp İçinde İmkân Sağlanırsa Üretim Yapmak } \\
\text { İsteyip İ́stemediği }\end{array}$ & \multicolumn{3}{c}{ Yüzde } \\
\hline Evet & $54,6 \%$ & $48,1 \%$ \\
\hline Hayır & $44,8 \%$ & $51,9 \%$ \\
\hline Toplam & $100 \%$ & $100 \%$ \\
\hline
\end{tabular}

Tablo 11'de kamp içindeki Suriyeli vatandaşların \% 55,2'si imkân sağlandığı takdirde üretim yapmak isterken $\% 44,8$ 'i üretim yapmak istememektedir. Üretim yapmak isteyen kadın oran1 \% 50 'den fazla olmasına rağmen, istemeyenlerin oranının da yüksek olduğunu görüyoruz. Bu duruma bağlı olarak bağımlı kadın oranının yüksek olduğunu söyleyebiliriz. 
Tablo 12. Kamp içinde yaşayan kadınlara imkân sağlanırsa yapmak istedikleri işlerin dă̆llımı

\begin{tabular}{lc} 
Üretim Yapma İmkânı Verilirse Yapmak İstenilen İşler & Toplam \% \\
\hline Ne olursa olsun & $30,4 \%$ \\
\hline Terzi & $21,7 \%$ \\
\hline El işleri & $15,9 \%$ \\
\hline Öğretmen & $14,5 \%$ \\
\hline Tarım & $10,1 \%$ \\
\hline Ticaret & $7,2 \%$ \\
\hline Toplam Yüzde & $100 \%$
\end{tabular}

Tablo 12'de kamp içinde yaşayan kadınlara imkân verilirse üretim yapmak isteyenlerin \%30,4'ü ne iş olursa olsun derken, \% 7,2'si ticaretle uğraşmak istemiştir. Kadınların tercih ettikleri mesleklere baktığımız zaman, kadına toplumsal rolde çizilen çerçevedeki meslekleri tercih ettiklerini söyleyebiliriz. Kadınların büyük çoğunluğunun da yapmak istedikleri işi tanımlayamadıkları dağılımda görülmektedir.

Tablo 13. Kamp içinde ve kamp dışında yaşayan kadınların çocuk bezine ulaşım dağılımları

\begin{tabular}{ccc} 
Çocuk Bezi & Kamp İçi & Kamp Dışı \\
\hline Çok Kolay & $24,6 \%$ & $10,6 \%$ \\
\hline Kolay & $40 \%$ & $20 \%$ \\
\hline Normal & $15,8 \%$ & $19,8 \%$ \\
\hline Zor & $13,8 \%$ & $41,9 \%$ \\
\hline Çok Zor & $5,8 \%$ & $7,6 \%$
\end{tabular}

Tablo 13’te kadınların \% 40’1 çocuk bezine kolay ulaşırken bu rakam kamp dışında \%20 'lere düşmektedir. Suriyeli kadınların çocuk bezine ulaşım oranları kamp içinde ve kamp dışında önemli oranda farklılık göstermektedir. Kamp içinde çocuk bezine ulaşım kolay iken kamp dışında zorlaşmaktadır. Bu farklılı̆̆ın kamplarda yapılan yardımlardan kaynaklandığı söylenebilir.

Tablo 14. Kamp içinde ve kamp dışında yaşayan kadınların, kendilerine yönelik özel ihtiyaçlarına ulaşım dă̆ılımları

\begin{tabular}{ccc}
$\begin{array}{c}\text { Kadınlara Yönelik } \\
\text { İhtiyaçlar }\end{array}$ & Kamp İçi & Kamp Dışı \\
\hline Çok Kolay & $24,6 \%$ & $9,6 \%$ \\
\hline Kolay & $41,9 \%$ & $22,6 \%$ \\
\hline Normal & $15,5 \%$ & $20,3 \%$ \\
\hline Zor & $13,4 \%$ & $40,2 \%$ \\
\hline Çok Zor & $6,8 \%$ & $7,4 \%$ \\
\hline
\end{tabular}


Tablo 14'te kadınların, özel ihtiyaçlarına \% 41,9'u kolay ulaşırken, bu rakam kamp dışında $\%$ 22,6'lara düşmektedir. Suriyeli kadınların, özel ihtiyaçlarına ulaşım oranları kamp içinde ve kamp dışında önemli oranda farklılık göstermektedir. Kamp içinde kadınların özel ihtiyaçlarına ulaşım kolay iken, kamp dışında zorlaşmaktadır. Bu farklılığın kamplarda yapılan yardımlardan kaynaklandığı söylenebilir.

\section{Kadın Hikâyeleri}

$\mathrm{Bu}$ çalışma çerçevesinde her kadının hikâyesi tek/kendine özgü olduğu için genellemeye gidilmeden tek tek ele alınarak toplumsal cinsiyet yaklaşımı üzerinden değerlendirilmeye çalışılmıştır. Suriyeli kadınlardan hikâyelerin paylaşılması için gerekli izinler alınmış olup, metin içerisinde paylaşılan isimler değiştirilerek verilmiştir.

i. AYŞE; Ayşe, 38 yaşında, evli, 3 çocuk annesi. Oğlu 6, kızlarından biri 3 diğeri 1 yaşında. Evlendikten sonra eşi farklı bir ülkeye giderek 1 yıl çalışmış ve kendi evlerini yaptırdıktan ve biraz birikim yaptıktan sonra geri dönmüş.

"Olaylar başladıktan bir süre sonra yaşadığımız şehre de yayıldı. Evimize çok yakın bir yere bomba düstü, çocuklar ile evde yalnızdım, çocukların o anki çığlıklarını ve camların patlamasını unutamıyorum. Patlamadan birkaç gün sonra ailecek akrabalarımıza gidiyorduk, evden çıkar çıkmaz evimize bomba düştü ve evimiz gözlerimizin önünde yand, tüm emeklerimiz birikimimiz kaybolup gitti. Çocuklarım o günden bu yana altlarına işemektedirler. O sırada 9 aylık hamile idim, 2 hafta kadar kayınvalidemler ile yaşadlk. Tekrar çatışmalar başladı ve muhalifler köyden bizi kurtardı. Türkiye'ye gelirken yolda doğum başladı ve sınır kapısında doğum gerçekleşti. x kampında yer olmadı̆̆ı için bir tanıdığımızın konteynerinde kalmaya başladık. Eşim fotoğrafçılıkla ilgilendiği için muhaliflerle 1 yıl önce Suriye'ye giderek savaş fotoğrafları çekmeye başladl. Bir daha geri dönmedi ve eşimden haber alamadım. Suriye'ye savaşmaya gidip gelenlerden bazıları eşimin yakalandığını ve fotoğraf çektiği için gözlerini oyduklarını ama hayatta olduğunu söylediler, onu bu şekilde hayal etmek bile çok zor. Bazı gidenler de hayatta olduğunu söylediler. Hangisinin gerçek olduğunu bilmiyorum, 1 yıldır ayn ikilem arasında gidip geliyorum. Artık çok yoruldum, işkence çekmesindense ölmüş olmasını umut ediyorum, en azından huzurlu olur. Kampta son 6 aydır iki konteyner arasını kapattı ve yere halı sererek orada yaşamaya başladık. Çoğu zaman komşuların yardımları ile geçiniyorum."

AFAD'dan gelen Sosyal Çalışmacılar olarak psikososyal destek sağladığımız süreçte kendisi ile görüştük. İkinci bireysel görüşmeye geldiği sırada çocuklarına yemek bırakmış fakat çocukları oyuna daldığ 1 için yemeği fareler yemiş ve onlara verecek yemeği olmadığ 1 için dayanamayıp bir kutu ilaç içerek intihar girişiminde bulunmuş. $10 \mathrm{dk}$. sonra çocuklarının ne olacağını düşünerek pişman olmuş, intihar ettiğini yakınlarına söyleyerek hastaneye kaldırılmış ve midesi yıkanarak kurtarılmış. Ayşe'nin intihar girişimi üzerine kamp yönetimi ile görüşülerek yeni kurulacak olan kampta konteynere yerleştirilmesi için gerekli işlemler yapıldı. Yapılan 5 görüşme sonunda kendisi ve çocukları için ayakta durması gerektiği ve onlar için hayatını yeniden kuracağını belirterek görüşmeler sonlandırılmıştır.

Savaş ve çatışma sürecinde siviller maddi ve manevi kayıplar yaşamaktadırlar. Maddi (ev, araba, eşya vb.) kayıplar ile birlikte emek ve hayalleri de yok olup gidebilmektedir. Savaşlar sırasında kadın ve çocuklar sağlık, barınma, beslenme, eğitim ve sosyal hizmetlerden daha fazla mahrum kalmakta ve mülteci durumuna düşebilmektedir (United Nations Development Fund For Women [UNIFEM], 2006). Bu süreçte doğru ve güvenilir bilgi kaynaklarına ulaşamamak kadınların yaşadığ1 belirsizliği ve ikilemi arttırmaktadır. Buna bağlı olarak kişide travma sonrası stres bozuklukları yaşanabilmektedir. Kadın çatışma ortamından uzaklaşsa bile yaşadığı depresyon, travma, anksiyete ve intihar gibi psikiyatrik bozuklukları devam edebilmektedir (UNIFEM, 2006). "Kadınlar eşlerini kaybettikleri ya da onlardan ayrıldıkları için kadınların sorumluluklarında ve rollerinde artış olmuştur. 
Kadın evin reisi haline gelmiş, kadınların bakım veren rolleri artmış, annelik rolleri yaşamlarında daha merkezi hale gelmiştir. Bu durum Abadan-Unat (1984, s.16-26); Canat (1982, s.13); Srilaskshmi (2000, s.13); Raghuram (2004, s. 3); Abdülrahim (1993, s. 65) ve Esra (2004:2001) tarafindan ifade edilmiştir (Buz, 2006). Suriyeli Ayşe'nin hikâyesi de bu bulguları desteklemektedir.

ii. Zeynep; Zeynep, 19 yaşında ve Şam'da iki katlı bir binanın ikinci katında ailesi ile oturmaktadır.

\begin{abstract}
"Bir gün evimizin balkonundan sofra bezi silkerken, sokakta Esad askerleri bir grubu kovalyordu ve o sırada marketten çılkan bir adam da ne olduğunu anlamadan kaçmaya başladı, fakat askerler onu yakaladı ve döverek ona elektrik vermeye başladılar. Adamın yalvarmalarına rağmen ona elektrik vermeye devam ettiler, adamdan kan geldi ve bayıldı sonrasında ise adamı sürüklediler ve tüm kan sokaklara bulaştı. Olaylar daha da şiddetlenince ablamların yaşadığ ş̧ehre taşındık. Bir süre sonrada Alevi- Sünni çatışmaları başladı. Bu nedenle ablamlarla beraber başka bir köye taşındık. Çok geçmeden buraya da baskına gelmeye başladılar. Baskına gelecekleri haberini alınca tüm kadınlar ve çocuklar ile caminin altındaki depoya saklandık. Saklandığımı depo karanlıktı ve toz, pislik, çamur, kir içindeydi, konuştuğumuzda tüm pislikler ağzımızdan içeri giriyordu. Erkeklerde dışarıda kalarak Esad'ın askerlerine karşı direndiler. Bir gece orada kaldık, küçük erkek kardeşimin kalbinde pil vardı ve kalbi durdu. O an ne yapacağımı bilemedim, ağllyordum ve çok korkmuştum; kardeşimin kafasını yıkadım ve kollarına masaj yaptım, sonra kendine geldi. Tüm gece çatışma seslerini dinledik. Sabaha karşı depodan dışarı çıktık ve ortalık toz duman içindeydi. Herkes yine kendi evlerine dağıldı ama çok korkuyorduk. 3 gün geçmeden köye bomba attılar ve minibüse düştü, tüm insanlar parçalandı ve ertesi gün insanların parçalanmış cesetlerini poşetlere topladılar, poşetlerden kanlar aklyordu. Bu olaydan sonra babam ve ailem kardeşimin tedavisi için Fransa'ya gitti. Ben de ablam ve eşi ile x kampına gelerek buraya sığındık. Şuanda nişanlıyım, sadece tekrar tüm ailemle bir arada olmak istiyorum. Ben de parçalanarak mı öleceğim diye korkuyorum."
\end{abstract}

Savaş ve çatışma süreci ile birlikte aileler parçalanmakta ve aile bağları kopmaktadır. Buna bağlı olarak kadınlar ve savaş mağdurları yaşadıkları sorunlarla baş etmede aile kaynaklarını kullanamamaktadır. Yaşanılan zorlu sürece ek olarak diğer aile üyelerine yönelik kaygılar yaşanabilmektedir. Kadınların tanık oldukları travmatik olaylar sonucunda travma sonrası stres bozuklukları ve depresyon yaşamaları kaçınılmaz olmaktadır. Aile ve Sosyal Politikalar Bakanlığı personeli tarafından Kilis’te gerçekleştirilen çalışma kapsamında 819 kişi ile yapılan görüşme sonucunda \% 74,75'inin savaş travmasından ağır bir şekilde etkilendiği tespit edilmiştir. (mustafacetinkaya80@gmail.com, 29 Temmuz 2013). Erkekler daha çok çatışma alanında yer alırken, kadınlar ise toplumsal rolleri çerçevesinde çocukları, yaşlıları vb. grupları koruyan kollama rollerini üstlenmektedir. Suriyeli Zeynep'in hikâyesinde bu bulguları görmekteyiz.

iii. Emine; Emine, 40 yaşında ve ev hanımı.

"Savaş başlamadan 1 yl önce eşimi kaybettim. Evim vardı ve maddi durumumuz da iyiydi, 2 oğlum da Esad'ın ordusunda görev yapıyordu. İ̧̧ çatı̧̧ma başladıktan sonra Esad'ın askerlerinden, iki oğlumdan birinin muhalif olduğunu düşündüklerini öğrenince oğlumu evimizin bodrumu olan bir masa altı kadar dar, sadece onun yatarak girebildiği bu yerde sakladım. Bodrum ile ev arasinda haberleşebilmek için iple zil düzeneği kurduk ve oğlumun dışarıya çıkmasını istediğimde o zille haberleşiyorduk. Dışarıya çıktı̆̆ zamanlarda oğluma kadın kiyafetleri ve peçe giydirerek onu sakladım bir süre. Kadındım ve çaresizdim, diğer oğlumun da aynı şeyleri yaşamasından, onu bulmalarından korkuyordum. Yalnızdım, ne yapacağımı, nereye gideceğimi, kimden yardım isteyeceğimi bilemiyordum. Aradan çok geçmeden Esad'ın askerleri gelerek saklandı̆̆ yerden oğlumu buldu ve ona gözümün önünde döverek elektrik verdiler ve onu sürükleyerek götürdüler. Onlara engel olmak istedim fakat bir asker beni kollarımdan tutuyordu, çok çaresizdim. Her şeyi izleyip hiçbir şey yapamadı̆̆ım, olanlara engel olamadığım için kendimi hâlâ çok suçlu hissediyorum. Sonra duydum ki diğer oğlumu da aynı suçla suçlamışlar ve her ikisine de işkence yapmışlar. Eve geldiklerinde ikisinin de iki bacağı, kendilerine karşı savaşmamaları için kurşunlanmıştı. Oğullarım serbest bırakıldıktan bir süre sonra, işkence yapılarak serbest bırakılan 6 arkadaşını da evimize getirdiler ve onları evde sakladık. 
Fakat çok geçmeden askerler tekrar geldi ve hepsini gözümüzün önünde tarayarak evimizi ateşe verdiler. Bu yüzden kendimi affedemiyorum, onları evimde saklamasaydım belki bulamazlardl. Bu olaydan sonra kalacak yerimiz kalmadı ve hiç kimsemiz olmadı̆̆ için çocuklarımı da alarak Türkiye'ye gelmek için yola çıtıtı, fakat bir gece boyunca boğazımıza kadar suyun içinde bekledik. Ertesi gün yola ıslak kıyafetlerimiz ile devam ettik. Türkiye'ye gelince oğullarımı kurtardığım için çok mutluydum, şükrediyordum fakat olanları aklımdan çıkarmam mümkün değil."

Savaş ve çatışma sürecinde tek başına olan kadınlar, ailelerinin annelik rollerinin yanı sıra babalık rollerini de yerine getirmektedir (Buz, 2006). Kadının iş yükünü ve sorumluluğunu arttıran bu durum, savaş ve çatışma hallerinde çok daha zorlayıcı olmaktadır. Toplumsal cinsiyete bağlı olarak erkekler çatışma alanlarında can güvenliğini sağlamaya çalışırken, kadınlar geri planda aile üyelerinin can güvenliğini sağlamak ve onları korumak zorunda kalmaktadır. Kadınların çatışma ortamlarında çaresizlik hissini çok yoğun olarak yaşadıkları ve bu hissi ifade ettikleri görülmektedir. Savaşlarda kadınların görevleri daha çok cephe gerisinde yaraları sarmak ve ihtiyacı olanlara yardım etmek olarak şekillenmektedir. Bu durum kadının aile içindeki rolü ile bire bir örtüşmektedir. Bu yardım sürecinin farklı sonuçlandığı durumlarda kadının kendisini suçlama davranışına meyilli olduğu görülmektedir. Suriyeli Emine'nin hikâyesinde olduğu gibi savaş ve çatışmalarda kendiliğinden gelişen rol dağılımlarının toplumsal cinsiyet rolleri ile paralellik gösterdiğini görüyoruz.

\section{Sonuç ve Öneriler}

Bu çalışma çerçevesinde Suriye iç savaşından kaçarak Türkiye'ye sığınan kadınların kadın profilleri sosyo-demografik veriler ve kadınlara özel durumlar çerçevesinde ortaya koyma çalışıldı. Türkiye'ye sığınan kadınlar ve erkekler arasında cinsiyet, yaş, medeni durum gibi sosyo-demografik özellikler açısından benzerlikler taşırken, söz konusu eğitim ve mesleki özellikler olduğu zaman farklılıklar görülmektedir. Kadınların özellikle meslekleri ve yapmayı tercih ettikleri işler açısından değerlendirildiğinde toplumsal cinsiyet rollerinin etkin olduğu görülmektedir.

Paylaşılan hikâyelerde de görüldüğü gibi kadınlar savaş, çatışma ve göç sürecinden erkeklere göre daha fazla etkilenmektelerdir. Kadınların sorumluluk ve rollerinde artış yaşanmaktadır. Sağlık, barınma, beslenme, eğitim ve sosyal hizmetler gibi temel insani hizmetlere ulaşmakta sorun yaşamaktadırlar. Toplumun her alanında olduğu gibi savaş, çatışma ve göç alanlarında en çok emek harcayan ve yer alan kadınlar iken, görünmez olarak kalan da yine kadınlar olmaktadır. Son zamanlarda bu konuda yapılan çalışmalarda artış olsa da daha özel kadın çalışmalarına ihtiyaç duyulmaktadır. Savaş ve göç sürecini anlatan birçok farklı kaynakta kadınların temel gereksinimlerine ve özelliklerine yönelik önerilerde bulunulmuştur. Bu çalışmada bunlardan farklı olarak şunlar önerilmektedir:

- Savaş, çatışma ve göç sürecine ilişkin politikalar üretilirken kadınların yaşadığı sorunları önlemeye yönelik toplumsal cinsiyete duyarlı politikalar geliştirilmelidir.

- Sunulan temel insani hizmetlerin yanında psikososyal destek hizmetlerinin de öncelikli çalışmalar arasında yer alması sağlanarak, kadınların yaşadıkları travmaların etkileri azalt1labilir.

- Aile reisi durumunda kalan kadınların desteklenmesine yönelik politika çalışmalarında bulunularak kadınların bu süreçte desteklenmesi sağlanabilir.

- Kadınlar savaş, çatışma ve göç sürecinde sürekli “mağdur” olarak değerlendirilmektedir. Özellikle hane reisi rolünü üstlenmek durumunda kalan kadınlar... Oysa onlara 
yönelik hizmetler ve politikalar geliştirilerek kadının toplumsal cinsiyet çerçevesindeki rolleri kırılarak gelişimi sağlanabilir. Bu sürecin getirdiği sorumluluk ve yeni roller kadının yeniden yapılanmasında bir araç olarak kullanılabilir

\section{Kaynakça}

Afet Raporu-Suriye. (b.t.). 05 Ekim 2013, http://www.afad.gov.tr/TR/IcerikDetay1.aspx?ID=16\&IcerikID=747

Aker,T., Ayata, B., Özeren, M., Buran, B. ve Bay, A. (2002). Zorunlu $\dot{I}_{c ̧}$ Göç: Ruhsal ve Toplumsal Sonuçları. 17 Ekim 2013, http://lokman.cu.edu.tr/psikiyatri/derindex/apd/fulltext/2002/97.pdf.

Akkaya, A. (2002). Mülteci Kadınlar ve Sığınmacı Kadınlar. Toplum ve Hukuk Dergisi, 2 (4), s.75-83.

Buz, S. (2006). Kadın ve Gö̧̧ Ilişkisi: Sı̆̆ınan ve Sı̆̆ınmacı Kadınlar Örneği. Yayınlanmamış doktora tezi, Hacettepe Üniversitesi Sosyal Bilimler Enstitüsü Sosyal Hizmet Anabilim Dalı.

Buz, S. (2008). Türkiye'deki Sığınmacıların Sosyal Profili. Polis Bilimleri Dergisi, 10(4), s.3.

Buz, S. (2008). Türkiye Sığınma Sisteminin Sosyal Boyutu. 05 Ekim 2013, http://tbbdergisi.barobirlik.org.tr/ m2008-77-434.

Çetin, T. (2008). Bulgaristan'daki Soydaşlarımızın Türkiye’ye Göç Etme Süreçlerini Etkileyen Bazı Değişkenlerin Incelenmesi. 05 Ekim 2013, tdae.ege.edu.tr/files/turhancetin.doc.

M. Çetinkaya (mustafacetinkaya80@gmail.com, 29 Temmuz 2013).

Çolak, F. (2013). Bulgaristan Türklerinin Türkiye’ye Göç Hareketi (1950-1951). 05 Ekim 2013, http://www.arastirmax.com/system/files/dergiler/175743/makaleler/14/arastrmx 175743 pp 113-145.pdf.

Inter-Afency Regional Response For Syrian Refugees. (n.d.). Retrieved August 14, 2013, fromdata//unhcr.org/ syrianrefuges/

İnternational Federation For Human Rights-FIDH. (2012). Violence Against Women in Syria: Breaking The Silence, Briefing Paper Based on an FIDH assessment mission in Jordan. 20 Ekim 2013, http://www.fidh. org/en/north-africa-middle-east/syria/Violence-against-women-in-Syria-Breaking-the-silence-13134

Moghadam, M.V. (2005). Peace bulding and Reconstruction with Women: Reflections on Afganistan, Iraqand Palestine. 07. Ekim 2013, http://insct.syr.edu/wp-content/uploads/2013/03/Moghadam-V.2005.Peacekeeping-and-Reconstruction-with-Women-in-Irag.pdf.

United Nations Development Fund For Women-UNIFEM. (2006). Gender and Conflict Analysis, UNIFEM Policy Briefing Paper. 20 Ekim 2013, http://www.unifem.org/attachments/gender_issues/women_war_peace/GenderAndConflictAnalysis_UNIFEMPolicyBriefingPaper_200610 en.pdf 